\title{
Pengaruh Pelaksanaan Program Keselamatan dan Kesehatan Kerja (K3) terhadap Produktivitas Kerja Karyawan pada PT. Bormindo Nusantara Duri
}

\author{
Muhammad Nur ${ }^{1}$, Chania Dwi Oktafia ${ }^{2}$ \\ Jurusan Teknik Industri, Fakultas Sains dan Teknologi, UIN Sultan Syarif Kasim Riau \\ Jl. HR. Soebrantas No. 155 Simpang Baru, Panam, Pekanbaru, 28293 \\ Email: muhammad.nur@uin-suska.ac.id
}

\begin{abstract}
ABSTRAK
PT. Bormindo Nusantara Duri merupakan perusahaan yang telah menerapkan Program Keselamatan dan Kesehatan Kerja (K3). Tetapi, meskipun PT. Bormindo Nusantara ini telah melaksanakan program Keselamatan dan Kesehatan Kerja (K3), tetap masih ada terjadi kecelakaan kerja yang disebabkan oleh beberapa faktor.Adanya fokus keselamatan dan kesehatan kerja (K3) zero accident diharapkan mampu meminimalisasikan resiko kecelakaan dan penyakit akibat kerja karena kondisi pekerja yang sehat berdampak pada produksi kerja yang baik dari pekerja itu sendiri.Oleh karena itu, dalam upaya meningkatkan produktivitas dengan memperhatikan aspek keselamatan dan kesehatan kerja (K3) pada maintenance departement, perusahaan perlu evaluasi keselamatan dan kesehatan kerjanya terhadap produktivitas kerja karyawan. Berdasarkan permasalahan yang terdapat pada PT. Bormindo Nusantara Duri maka untuk mengetahui berapa jumlah jam kerja yang hilang akibat kecelakaan kerja digunakanlah perhitungan lost time injuryfrequency ratedan untuk mengetahui pengaruh variabel yang diteliti digunakanlah metode uji regresi linier berganda untuk mengetahui pengaruh dari variabel bebas terhadap variabel terikat yaitu keselamatan kerja $\left(\mathrm{X}_{1}\right)$ dan kesehatan kerja $\left(\mathrm{X}_{2}\right)$ sebagai variabel independent $(\mathrm{X})$ dan produktivitas kerja karyawan sebagai variabel dependent $(\mathrm{Y})$ dengan menggunakan softwareSPSS 16.00. Hasil penelitian ini menyatakan bahwa keselamatan dan kesehatan kerja mempunyai hubungan yang positif terhadap produktivitas kerja karyawan, hal itu dapat dilihat dari nilai $\mathrm{r}$ sebesar 0,736. Selain itu dari hasil pengolahan data dapat diketahui bahwa 26,4\% produktivitas kerja karyawan dipengaruhi oleh faktor-faktor lainnya.
\end{abstract}

Kata Kunci: Keselamatan dan Kesehatan Kerja, Produktivitas Kerja Karyawan

\section{Pendahuluan}

Memasuki perkembangan era industrialisasi global, persaingan industri untuk memperebutkan pasar baik tingkat regional, nasional, maupun internasional, dilakukan oleh setiap perusahaan secara kompetitif. Industrialisasi tidak terlepas dari sumber daya manusia, dimana setiap manusia diharapkan dapat menjadi sumber daya siap pakai dan mampu membantu tercapainya tujuan perusahaan (Pangarso, 2014).

Setiap perusahaan mengharapkan dapat menghasilkan produk berkualitas tinggi. Kualitas produk yang dihasilkan tidak terlepas dari peranan sumber daya manusia (SDM) yang dimilki perusahaan. Untuk itu, Perusahaan akan selalu berupaya mengoptimalkan seluruh sumber daya manusia (SDM) agar tujuan perusahaan tersebut dapat tercapai. Sumber daya manusia (SDM) yang berkualitas akan mampu mengolah faktorfaktor produksi dalam perusahaan seperti modal, mesin, metode, uang, dan bahan baku dengan baik. Ketika mengolah faktor-faktor produksi, sumber daya manusia (SDM) sebagai tenaga kerja tidak terlepas dari masalahmasalah kerja yang berkaitan dengan keselamatan dan kesehatan kerja (Hutasoit, 2011). 
Masalah keselamatan dan kesehatan kerja bukan semata-mata tanggung jawab pemerintah tetapi merupakan tanggung jawab semua pihak terutama pengusaha, tenaga kerja dan masyarakat. Keselamatan dan Kesehatan Kerja (K3) adalah suatu program yang dibuat pekerja maupun pengusaha sebagai upaya mencegah timbulnya kecelakaan dan penyakit akibat kerja dengan cara mengenali hal-hal yang berpotensi menimbulkan kecelakaan dan penyakit akibat kerja serta tindakan antisipatif apabila terjadi kecelakaan dan penyakit akibat kerja. Tujuan dari dibuatnya program Keselamatan dan Kesehatan Kerja (K3) adalah untuk mengurangi biaya perusahaan apabila timbul kecelakaan dan penyakit akibat kerja (Lestari, 2007).

PT. Bormindo Nusantara Durimerupakan perusahaan yang berdiri pada 22 Mei 1980. Perusahaan ini bergerak di bidang jasa Pengeboran (Drilling) dan Perawatan Sumur Minyak (Workover) pada perusahaan minyak bumi, gas dan panas bumi yang beroperasi di wilayah Republik Indonesia. PT. Bormindo Nusantara ini telah melaksanakan program Keselamatan dan Kesehatan Kerja (K3), tetap masih ada terjadi kecelakaan kerja yang disebabkan oleh beberapa faktor.Adanya fokus zero accident dari Health, Enviroment, and Safety pada PT. Bormindo Nusantara yaitu tidak ada lagi kecelakaan di lokasi kerja baik itu yang bersifat cidera memerlukan pertolongan pertama atau P3K hingga mengakibatkan fatality. Dengan adanya fokus keselamatan dan kesehatan kerja (K3) ini diharapkan mampu meminimalisasikan resiko kecelakaan dan penyakit akibat kerja karena kondisi pekerja yang sehat berdampak pada produksi kerja yang baik dari pekerja itu sendiri. Semakin produktif pekerja maka produktivitas kerja pun dapat meningkat dan dapat mendukung keberhasilan bisnis perusahaan.

\section{Tinjauan Pustaka}

\section{Keselamatan Kerja}

Keselamatan kerja adalah keselamatan yang bertalian dengan mesin, pesawat, alat kerja, bahan dan proses pengolahannya, landasan tempat kerja dan lingkungannya serta cara-cara melakukan pekerjaan. Keselamatan Kerja adalah sarana utama untuk mencegah kecelakaan, cacat dan kematian sebagai akibat kecelakaan kerja. Keselamatan kerja yang baik adalah pintu gerbang bagi keamanan tenaga kerja (Suma'mur, 1989).

Kewajiban perusahaan dapat disimpulkan sebagai berikut (Hariandja, 2002 dikutip oleh Hutasoit, 2011):

a. Memelihara tempat kerja yang aman dan sehat bagi pekerja,

b. Mematuhi semua standar dan syarat kerja,

c. Mencatat semua peristiwa kecelakaan yang terjadi berkaitan dengan Keselamatan Kerja.

Keselamatan kerja menurut American Society of Safety Engineers (ASSE) dalamSugeng (2005) diartikan sebagai bidangkegiatan yang ditujukan untuk mencegah semua jenis kecelakaan yangada kaitannya dengan lingkungan dan situasi kerja (Lestari, 2007).

\section{Kesehatan Kerja}

Menurut Yuli (2005), kesehatan kerja menunjukkan kondisi yang bebas dari gangguan fisik, mental, emosi atau rasa sakit yang disebabkan oleh lingkungan kerja. Menurut Mathis dan Jakson (2002) bahwa individu yang sehat adalah yang bebas dari penyakit, cidera serta masalah mental dan emosi yang bisa menggangu aktivitas manusia normal. Praktik manajemen kesehatan di perusahaan bertujuan untuk memelihara kesejahteraan individu secara menyeluruh (Hutasoit, 2011).

Kesehatan Kerja dibedakan menjadi dua, yaitu sebagai berikut (Menurut Flippo dalam Panggabean, 2004 dikutip oleh Hutasoit, 2011):

a. Physical Health, berupa :

1) Pemeriksaan jasmani prapenempatan,

2) Pemeriksaan jasmani secara berkala dan sukarela untuk semua personalia, 
3) Klinik medis yang mempunyai staf dan perlengkapan yang baik,

4) Perhatian yang sistematik dan preventif yang dicurahkan pada tekanan dan ketegangan industri.

b. Mental Health, yang antara lain berupa :

1) Tersedianya penyuluhan dan psikiater

2) Pendidikan personalia perusahaan sehubungan dengan hakikat dan pentingnya masalah kesehatan mental

3) Pengembangan dan pemeliharaan program hubungan kemanusiaan yang tepat.

\section{Tujuan Keselamatan}

dan

\section{Kesehatan Kerja}

Tujuan keselamatan dan kesehatan kerja adalah sebagai berikut (Mangkunegara, 2001 dikutip oleh Lestari, 2007):

a. Setiap pegawai mendapat jaminan keselamatan dan kesehatan kerja baik secara fisik, sosial dan psikologis.

b. Setiap perlengkapan dan peralatan kerja digunakan sebaikbaiknya dan seefektif mungkin.

c. Semua hasil produksi dipelihara keamanannya.

d. Adanya jaminan atas pemeliharaan dan peningkatan kesehatan gizi pegawai.

e. Meningkatkan kegairahan, keserasian kerja dan partisipasi kerja.

f. Terhindar dari gangguan kesehatan yang disebabkan oleh lingkungan atau kondisi kerja.

g. Setiap pegawai merasa aman dan terlindungi dalam bekerja.

\section{Kecelakaan Kerja}

Kecelakaan adalah suatu kejadian tak diduga dan tidak dikehendaki yang mengacaukan proses suatu aktivitas yang telah diatur (Sulaksmono dalam Santoso, 2004, dikutip oleh Lestari, 2007).
Kecelakaan kerja adalah suatu kejadian atau peristiwa yang tidak diinginkan yang merugikan terhadap manusia, merusak harta benda atau kerugian terhadap proses. Secara umum kecelakaan kerja dibagi menjadi dua golongan, yaitu (Sugeng, 2005 dikutip oleh Lestari, 2007),

a. Kecelakaan industri (industrial accident) yaitu kecelakaan yang terjadi di tempat kerja karena adanya sumber bahaya atau bahaya kerja.

b. Kecelakaan dalam perjalanan (community accident) yaitu kecelakaan yang terjadi diluar tempat kerja yang berkaitan dengan adanya hubungan kerja.

\section{Faktor-faktor Kecelakaan}

Kecelakaan kerja dapat disebabkan oleh beberapa faktor, yaitu (Hariandja, 2002 dikutip oleh Hutasoit, 2011):

a. Faktor manusia

Manusia memiliki keterbatasan, dalam arti bisa lelah, lalai, atau melakukan kesalahan yang di sebabkan persoalan pribadi atau keterampilan yang kurang dalam melakukan pekerjaan. Untuk mengatasi hal ini, perusahaan melakukan pelatihan, membuat pedoman pelaksanaan kerja secara tertulis, meningkatkan disiplin, melakukan pengawasan oleh atasan langsung, dan memberikan reward bagi yang mengikuti prosedur dengan benar.

b. Faktor peralatan kerja

Peralatan kerja atau pelindung bisa rusak atau tidak memadai. Untuk itu perusahaan senantiasa memperhatikan kelayakan setiap peralatan yang dipakai dan melatih para pegawai untuk memahami karakteristik setiap peralatan dan mekanisme kerja peralatan tersebut.

c. Faktor lingkungan kerja

Lingkungan kerja bisa menjadi tempat yang tidak aman, penerangan dan 
ventilasinya tidak memadai, iklim psikologis diantara pekerja kurang baik. Jadi, perusahaan harus membangun teamwork yang baik melalui bermacam program.

\section{Alat Pelindung Diri (APD)}

Alat Pelindung Diri (APD) adalah seperangkat alat keselamatan yang digunakan oleh pekerja untuk melindungi seluruh atau sebagian tubuhnya dari kemungkinan adanya pemaparan potensi bahaya lingkungan kerja terhadap kecelakaan dan penyakit akibat kerja (Tarwaka, 2008 dikutip oleh Wulansari, 2009).

\section{Lost Time Frequency Rate}

Lost Time Injury or Diseases merupakan kejadian yang mengakibatkan kematian, cacat permanen, kehilangan waktu bekerja selama satu hari atau lebih yang diakibatkan kecelakaan kerja. LTFR merupakan salah satu metode analisis untuk menilai level kesehatan dan keselamatan di tempat kerja secara silang antara aturan, pelatihan, dan tingkah laku. Lost Time Injury Frequency Rate atau yang sering disingkat LTIFR atau LTFR merupakan jumlah waktu yang hilang akibat cedera atau kecelakaan kerja per satu juta jam kerja pekerja. Untuk menghitung rasio jumlah cedera atau kecelakaan kerja yang mengakibatkan lost time per satu jam kerja pekerja, maka rumusnya adalah sebagai berikut (Perdana dkk, 2012):

LTIFR $=\frac{\text { Banyak Kecelakaan } \times 1.000 .000}{\text { Total Jam Kerja Manusia }}$

\section{Produktivitas Kerja Karyawan}

Produktivitas kerja merupakan hal yang sangat menarik karena mengukur hasil kerja manusia dengan segala masalahnya. Pengukuran produktivitas kerja menurut sistem pemasukan fisik perorangan atau per orang per jam kerja diterima secara luas, namun dari sudut pandang atau pengawasan harian, pengukuran tersebut pada umumnya tidaklah memuaskan, karena adanya variasi dalam jumlah yang diperlukan untuk memproduksi satu unit produk yang berbeda. Oleh karena itu digunakan metode pengukuran waktu tenaga kerja (jam, hari atau tahun), pengeluaran diubah ke dalam unit-unit pekerja yang biasanya diartikan sebagai jumlah kerja yang dapat dilakukan dalam satu jam oleh pekerja yang terpercaya yang bekerja menurut pelaksanaan standar. Produktivitas kerja dipengaruhi oleh beberapa faktor dan dapat dilihat dari kemauan kerja yang tinggi, kemampuan kerja yang sesuai dengan isi kerja, lingkungan kerja yang nyaman, penghasilan yang dapat memenuhi kebutuhan hidup minimum, jaminan sosial yang memadai, dan hubungan kerja yang harmonis (Sinungan, 2005 dikutip oleh Lestari, 2007).

Program produktivitas dapat

dipandang sebagai suatu sistem yang mencakup empat tahapan. Model lingkaran produktivitas adalah sebagai berikut:



Gambar 1 Model Lingkaran Produktivitas

(Sumber: Ervianto, 2005 dikutip oleh Hutasoit, 2011)

\section{Metodologi Penelitian}

Berikut adalah metodologi penelitian berupa tahap yang tergambar pada diagram alir, yaitu: 


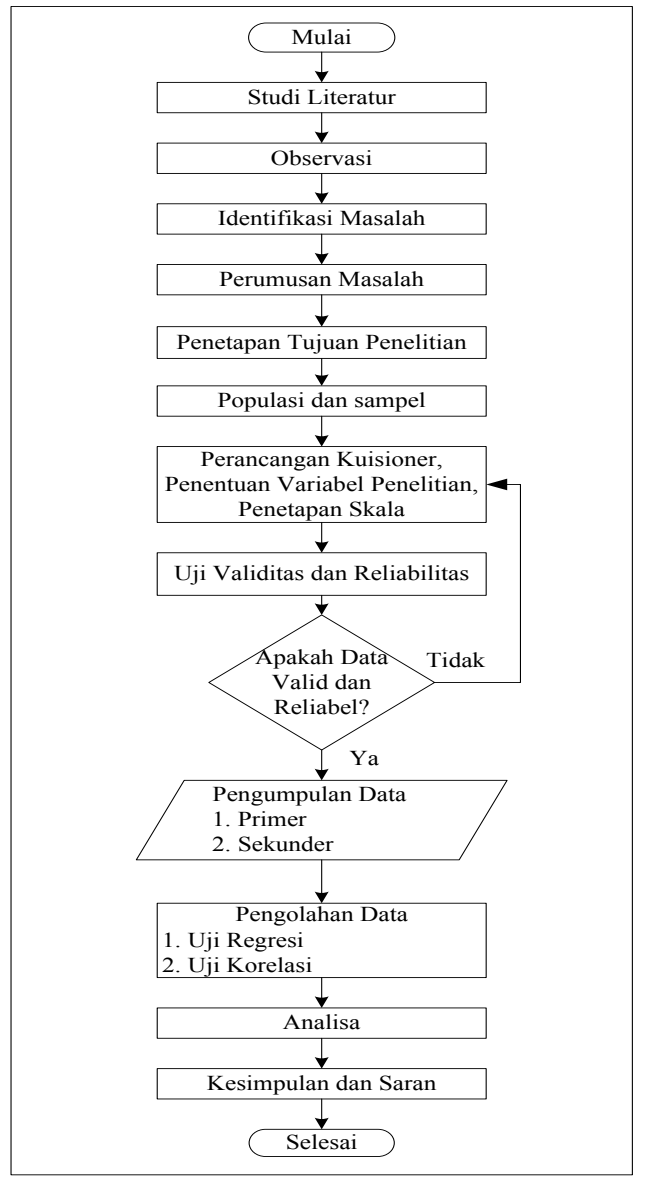

\section{Populasi}

Adapun populasi pada penelitian ini adalah karyawan maintenance departementPT. Bormindo Nusantara Duri yaitu berjumlah 39 orang.

\section{Sampel}

Untuk pengambilan sampel dari populasi yang berjumlah 39 karyawan tersebut penulis menggunakan rumus Slovin, dengan rumus sebagai berikut:

$$
n=\frac{N}{1+N e^{2}}
$$

Keterangan:

$\mathrm{n}=$ Ukuran contoh

$\mathrm{N}=$ Ukuran populasi

$\mathrm{e}=$ Persen kelonggaran ketidaktelitian akibat kesalahan pengambilan contoh yang masih bisa ditolerir dengan asumsi populasi berdistribusi

Pada penelitian ini penulis menetapkan persen kelonggaran 10\%, sehingga hasil perhitungan pengambilan sampel sebagai berikut:

$$
\begin{aligned}
& n=\frac{39}{1+(39)(0,1)^{2}} \\
& =28,06 \text { atau } 28
\end{aligned}
$$

Sehingga berdasarkan perhitungan diatas maka dapat diketahui bahwa sampel yang akan diambil dari penelitian ini berjumlah 28 responden.

\section{Perancangan Kuisioner, Penentuan Variabel Penelitian dan Penentuan \\ Skala}

Alat pengumpul data yang digunakan adalah kuisioner yang berbentuk rangkaian atau kumpulan pertanyaan yang disusun secara sistematis mengenai masalah yang akan diteliti, kuisioner yang dirancang disesuaikan dengan variabel-variabel yang telah ditentukan. Menentukan variabel yang digunakan dalam penelitian menjadi sangat penting dan mengetahui setiap pengaruh yang ada pada pada produktivitas kerja karyawan. Maka dari itu peneliti menentukan variabel yang mempengaruhi produktivitas kerja karyawan, keselamatan kerja dan kesehatan kerja. Setelah itu dirancang kuisioner berdasarkan variabel, variabel terbagi 2 yaitu variabel terikat dan variabel bebas.

Skor yang digunakan dalam penelitian ini menggunakan skala likert dengan kriteria skor sebagai berikut:

Tabel 1 Skala Penilaian

\begin{tabular}{|l|c|}
\hline \multicolumn{1}{|c|}{ Tingkat Persetujuan } & Skor \\
\hline Sangat Tidak Setuju & 1 \\
\hline Tidak Setuju & 2 \\
\hline Ragu-ragu & 3 \\
\hline Setuju & 4 \\
\hline Sangat Setuju & 5 \\
\hline
\end{tabular}

\section{Uji Validitas dan Reliabilitas}

Uji validitas dan reliabilitas dilakukan pada instrumen penelitian, dalam hal ini adalah kuesioner, untuk menguji apakah kuesioner 
layak digunakan sebagai instrument penelitian. Valid berarti instrument tersebut dapat digunakan untuk mengukur apa yang seharusnya diukur dan reliabel berarti instrumen yang digunakan beberapa kali mengukur objek yang sama, akan menghasilkan data yang sama (Widodo, 2006).

\section{Uji Regresi dan Korelasi}

Uji regresi ini dapat dijadikan sebagai alat bantu yang digunakan untuk menganalisis hubungan keselamatan dan kesehatan kerja terhadap produktivitas kerja karyawan.

Apabila terdapat hubungan antara variabel bebas dengan variabel terikat maka dilanjutkan dengan uji kolerasi. Uji kolerasi ini merupakan isitlah yang digunakan untuk mengukur kekuatan atau ada tidaknya hubungan antar variabel.

\section{Hasil dan Pembahasan}

\section{Perhitungan Lost Time Injury FrequencyRate}

Tabel 2 Data Kecelakaan Kerja Karyawan PT.

Bormnido Nusantara

\begin{tabular}{|c|c|}
\hline Tahun & Jumlah Kecelakaan Kerja \\
\hline 2014 & 5 Orang \\
\hline 2015 & 3 Orang \\
\hline 2016 & 6 Orang \\
\hline Jumlah & 14 Orang \\
\hline
\end{tabular}

(Sumber: PT. Bormindo Nusantara, 2017)

Tabel 3 Rekapitulasi Hasil Perhitungan Lost Time Injury Frequency Rate

\begin{tabular}{|c|c|c|c|}
\hline Tahun & $\begin{array}{c}\text { Jumlah } \\
\text { Kecelakaan } \\
\text { Kerja }\end{array}$ & $\begin{array}{c}\text { Jumlah } \\
\text { Jam } \\
\text { Kerja/ } \\
\text { Tahun }\end{array}$ & $\begin{array}{c}\text { Jumlah } \\
\text { LTIFR } \\
\text { (jam) }\end{array}$ \\
\hline 2014 & 5 & 97.344 & 51,36 \\
\hline 2015 & 3 & 97.344 & 30,82 \\
\hline 2016 & 6 & 97.344 & 61,64 \\
\hline
\end{tabular}

\section{Uji Validitas}

Pengujian ini menggunakan tingkat signifikansi dengan nilai $\alpha=0,05$ dan $\mathrm{Df}=26$ serta jumlah pertanyaan dalam pengujian ini adalah26pertanyaan.
Tabel 4 Rekapitulasi Perhitungan Uji Validitas

\begin{tabular}{|c|c|c|c|c|}
\hline Pertanyaan & $\mathbf{R}_{\text {hitung }}$ & $\mathbf{R}_{\text {tabel }}$ & Kriteria & Keterangan \\
\hline 1 & 0,551 & 0,374 & $\mathrm{R}_{\text {hitung }}>\mathrm{R}_{\text {tabel }}$ & Valid \\
\hline 2 & 0,737 & 0,374 & $\mathrm{R}_{\text {hitung }}>\mathrm{R}_{\text {tabel }}$ & Valid \\
\hline 3 & 0,793 & 0,374 & $\mathrm{R}_{\text {hitung }}>\mathrm{R}_{\text {tabel }}$ & Valid \\
\hline 4 & 0,802 & 0,374 & $\mathrm{R}_{\text {hitung }}>\mathrm{R}_{\text {tabel }}$ & Valid \\
\hline 5 & 0,505 & 0,374 & $\mathrm{R}_{\text {hitung }}>\mathrm{R}_{\text {tabel }}$ & Valid \\
\hline 6 & 0,493 & 0,374 & $\mathrm{R}_{\text {hitung }}>\mathrm{R}_{\text {tabel }}$ & Valid \\
\hline 7 & 0,580 & 0,374 & $\mathrm{R}_{\text {hitung }}>\mathrm{R}_{\text {tabel }}$ & Valid \\
\hline 8 & 0,556 & 0,374 & $\mathrm{R}_{\text {hitung }}>\mathrm{R}_{\text {tabel }}$ & Valid \\
\hline 9 & 0,393 & 0,374 & $\mathrm{R}_{\text {hitung }}>\mathrm{R}_{\text {tabel }}$ & Valid \\
\hline 10 & 0,531 & 0,374 & $\mathrm{R}_{\text {hitung }}>\mathrm{R}_{\text {tabel }}$ & Valid \\
\hline 11 & 0,547 & 0,374 & $\mathrm{R}_{\text {hitung }}>\mathrm{R}_{\text {tabel }}$ & Valid \\
\hline 12 & 0,617 & 0,374 & $\mathrm{R}_{\text {hitung }}>\mathrm{R}_{\text {tabel }}$ & Valid \\
\hline 13 & 0,431 & 0,374 & $\mathrm{R}_{\text {hitung }}>\mathrm{R}_{\text {tabel }}$ & Valid \\
\hline 14 & 0,715 & 0,374 & $\mathrm{R}_{\text {hitung }}>\mathrm{R}_{\text {tabel }}$ & Valid \\
\hline 15 & 0,559 & 0,374 & $\mathrm{R}_{\text {hitung }}>\mathrm{R}_{\text {tabel }}$ & Valid \\
\hline 16 & 0,800 & 0,374 & $\mathrm{R}_{\text {hitung }}>\mathrm{R}_{\text {tabel }}$ & Valid \\
\hline 17 & 0,666 & 0,374 & $\mathrm{R}_{\text {hitung }}>\mathrm{R}_{\text {tabel }}$ & Valid \\
\hline 18 & 0,572 & 0,374 & $\mathrm{R}_{\text {hitung }}>\mathrm{R}_{\text {tabel }}$ & Valid \\
\hline 19 & 0,630 & 0,374 & $\mathrm{R}_{\text {hitung }}>\mathrm{R}_{\text {tabel }}$ & Valid \\
\hline 20 & 0,802 & 0,374 & $\mathrm{R}_{\text {hitung }}<\mathrm{R}_{\text {tabel }}$ & Valid \\
\hline 21 & 0,586 & 0,374 & $\mathrm{R}_{\text {hitung }}>\mathrm{R}_{\text {tabel }}$ & Valid \\
\hline 22 & 0,794 & 0,374 & $\mathrm{R}_{\text {hitung }}>\mathrm{R}_{\text {tabel }}$ & Valid \\
\hline 23 & 0,794 & 0,374 & $\mathrm{R}_{\text {hitung }}>\mathrm{R}_{\text {tabel }}$ & Valid \\
\hline 24 & 0,737 & 0,374 & $\mathrm{R}_{\text {hitung }}>\mathrm{R}_{\text {tabel }}$ & Valid \\
\hline 25 & 0,793 & 0,374 & $\mathrm{R}_{\text {hitung }}<\mathrm{R}_{\text {tabel }}$ & Valid \\
\hline 26 & 0,518 & 0,374 & $\mathrm{R}_{\text {hitung }}>\mathrm{R}_{\text {tabel }}$ & Valid \\
\hline
\end{tabular}

\section{Uji Validitas}

Output nilai Cronbach's Alpha (nilainya berkisar antara 0-1) yang digunakan sebagai perbandingan untuk melihat konsistensi jawaban responden. Semakin besar nilai cronbach's alpha (semakin mendekati 1), maka kuesioner tersebut semakin reliabel.

Tabel 5Output Reliability Statistics

\begin{tabular}{|c|c|}
\hline Cronbach's Alpha & N of Items \\
\hline 0,949 & 26 \\
\hline
\end{tabular}

\section{Output Regresi Linear Berganda}

a. Output Descriptive Statistic

Tabel 6OutputDescriptive Statistics 


\begin{tabular}{|l|c|c|c|}
\hline \multicolumn{1}{|c|}{ Variabel } & Mean & $\begin{array}{c}\text { Std. } \\
\text { Deviation }\end{array}$ & N \\
\hline $\begin{array}{l}\text { Produktivitas } \\
\text { Kerja } \\
\text { Karyawan }\end{array}$ & 45,71 & 3,876 & 28 \\
\hline $\begin{array}{l}\text { Keselamatan } \\
\text { Kerja }\end{array}$ & 36,86 & 3,064 & 28 \\
\hline $\begin{array}{l}\text { Kesehatan } \\
\text { Kerja }\end{array}$ & 36,89 & 3,563 & 28 \\
\hline
\end{tabular}

b. Uji Determinasi $\left(\mathrm{R}^{2}\right)$

Tabel 7Output Model Summary

\begin{tabular}{|c|c|c|c|}
\hline $\boldsymbol{R}$ & $\begin{array}{c}\boldsymbol{R} \\
\text { Square }\end{array}$ & $\begin{array}{c}\text { Adjusted } \boldsymbol{R} \\
\text { Square }\end{array}$ & $\begin{array}{c}\text { Std. Error of the } \\
\text { Estimate }\end{array}$ \\
\hline $0,869^{\mathrm{a}}$ & 0,756 & 0,736 & 1,991 \\
\hline
\end{tabular}

Berdasarkan output Tabel 7 tampak bahwa dari hasil perhitungan diperoleh nilai koefisien determinasi sebesar 0,736 yang mengindikasikan bahwa sebesar $73,6 \%$ adanya pengaruh keselamatan dan kesehatan kerja terhadap produktivitas kerja karyawan.

\section{c. Uji F}

Pengujian ini dilakukan untuk mengetahui apakah semua variabel independent secara bersama-sama (simultan) dapat berpengaruh terhadap variabel dependent. Cara yang digunakan adalah dengan membandingkan nilai $F_{\text {hitung }}$ dengan $F_{\text {tabel }}$ dengan ketentuan sebagai berikut:

1) Jika $F_{\text {hitung }}>F_{\text {tabel, maka variabel } X}$ mempunyai keeratan hubungan yang signifikan terhadap variabel $\mathrm{Y}$.

2) Jika $F_{\text {hitung }}<F_{\text {tabel }}$, maka variabel $X$ tidak mempunyai keeratan hubungan yang signifikan terhadap variabel $\mathrm{Y}$.

Tabel 8 Uji F

\begin{tabular}{|l|c|c|c|c|}
\hline Model & $\begin{array}{c}\text { Sum of } \\
\text { Squares }\end{array}$ & $\begin{array}{c}\text { Mean } \\
\text { Square }\end{array}$ & F & Sig. \\
\hline Regression & 306,618 & 153,309 & 38,677 & $0,000^{\mathrm{a}}$ \\
\hline Residual & 99,096 & 3,964 & & \\
\hline Total & 405,714 & & & \\
\hline
\end{tabular}

Dari Tabel 8 menunjukkan hasil dari uji f yang menghasilkan $F_{\text {hitung }}=38,677>$ dari $\mathrm{F}_{\text {tabel }}=3,39$ Oleh karena itu dapat disimpulkan bahwa variabel keselamatan dan kesehatan kerja berpengaruh secara signifikan terhadap produktivitas kerja karyawan PT. Bormindo Nusantara Duri.

\section{d. Output Coefficients}

Pada output coefficients ini digunakan untuk mengetahui apakah model regresi variabel keselamatan kerja $\left(\mathrm{X}_{1}\right)$ dan kesehatan kerja $\left(X_{2}\right)$ secara parsial berpengaruh signifikan terhadap produktivitas kerja karyawan $(\mathrm{Y})$.

Tabel 9OutputCoefficients

\begin{tabular}{|l|c|c|c|c|c|c|}
\hline \multirow{2}{*}{ Model } & \multicolumn{2}{|c|}{$\begin{array}{c}\text { Unstandardized } \\
\text { Coefficients }\end{array}$} & $\begin{array}{c}\text { Standar-dized } \\
\text { Coeffici-ents }\end{array}$ & \multirow{2}{*}{ T Sig. } \\
\cline { 2 - 5 } & B & $\begin{array}{c}\text { Std. } \\
\text { Error }\end{array}$ & \multicolumn{2}{|c|}{ Beta } & & \\
\hline (Constant $)$ & 7,995 & 4,632 & & 1,726 & 0,097 \\
\hline $\begin{array}{l}\text { Keselamatan } \\
\text { Kerja }\end{array}$ & 0,309 & 0,224 & 0,244 & 1,378 & 0,180 \\
\hline $\begin{array}{l}\text { Kesehatan } \\
\text { Kerja }\end{array}$ & 0,714 & 0,193 & 0,656 & 3,702 & 0,001 \\
\hline
\end{tabular}

Berdasarkan hasil analisis regresi pada Tabel 9 maka dapat disusun suatu persamaan regresi linear berganda yaitu sebagai berikut:

$\hat{\mathrm{Y}}=\mathrm{a}+\mathrm{b}_{1} \mathrm{X}_{1}+\mathrm{b}_{2} \mathrm{X}_{2}$

$\hat{\mathrm{Y}}=7,995+0,309 \mathrm{X}_{1}+0,714 \mathrm{X}_{2}$

Dimana:

$\hat{\mathrm{Y}}=$ Variabel terikat (dependent variabel)

$\mathrm{X}=$ Variabel bebas (independent variabel)

a $=$ Kostantan

$\mathrm{b}_{1} \mathrm{X}_{1}=$ Keselamatan Kerja

$b_{2} X_{2}=$ Kesehatan Kerja

e. Uji Hipotesis

Untuk membuktikan bahwa hipotesis dalam penelitian ini diterima maka dengan menggunakan tingkat koefisiensi masingmasing variabel penulis akan menguji hubungan dan pengaruh pengaruh keselamatan dan kesehatan kerja terhadap produktivitas kerja karyawan dengan ketentuan sebagai berikut.

1) Pengaruh keselamatan kerja terhadap produktivitas kerja karyawan

$\mathrm{H}_{0}: \beta 1=\beta 2=0$ 
Berarti pengaruh keselamatan kerja tidak mempunyai pengaruh signifikan produktivitas kerja karyawan.

$\mathrm{H}_{1}: \beta 1 \neq \beta 2 \neq 0$

Berarti pengaruh keselamatan kerja mempunyai pengaruh yang signifikan terhadap produktivitas kerja karyawan.

2) Pengaruh kesehatankerja terhadap produktivitas kerja karyawan

$\mathrm{H}_{0}: \beta 1=\beta 2=0$

Berarti pengaruh kesehatan kerja tidak mempunyai pengaruh signifikan terhadap produktivitas kerja karyawan.

$\mathrm{H}_{1}: \beta 1 \neq \beta 2 \neq 0$

Berarti pengaruh kesehatan kerja mempunyai pengaruh yang signifikan terhadap produktivitas kerja karyawan.

$\mathrm{T}_{\text {hitung }}>\mathrm{T}_{\text {tabel }}=\mathrm{H}_{0}$ ditolak dan $\mathrm{H}_{1}$ diterima

$\mathrm{T}_{\text {hitung }}<\mathrm{T}_{\text {tabel }}=\mathrm{H}_{1}$ ditolak dan $\mathrm{H}_{0}$ diterima

3) Persentase alpha ditentukan sebesar 0,05 dengan jumlah sampel $(\mathrm{N})$ adalah 28 dan derajat kebebasan $\mathrm{N}-2$.

Derajat kebebasan $(\mathrm{dk})=28-2$

$$
=26
$$$$
\text { Maka } \mathrm{t}_{\text {tabel }}(0,05 ; 26)=2,06
$$

Tabel 10 Hasil Perhitungan Uji Hipotesis

\begin{tabular}{|c|c|c|}
\hline Hipotesis & Nilai & Keterangan \\
\hline $\begin{array}{l}\text { Variabel } \\
\text { keselamatan kerja } \\
\text { tidak berpengaruh } \\
\text { signifikan } \\
\text { terhadap } \\
\text { produktivitas } \\
\text { kerja karyawan }\end{array}$ & $\begin{array}{l}\mathrm{t}_{\text {hitung }}= \\
1,378 \\
\mathrm{t}_{\text {tabel }}= \\
2,06\end{array}$ & $\begin{array}{l}\mathrm{H}_{0} \text { diterima } \\
\text { dan } \\
\mathrm{H}_{1} \text { ditolak }\end{array}$ \\
\hline $\begin{array}{l}\text { Variabel } \\
\text { kesehatan kerja } \\
\text { berpengaruh } \\
\text { signifikan } \\
\text { terhadap kinerja } \\
\text { karyawan }\end{array}$ & $\begin{array}{l}\mathrm{t}_{\text {hitung }}= \\
3,702 \\
\mathrm{t}_{\text {tabel }}= \\
2,06\end{array}$ & $\begin{array}{l}\mathrm{H}_{0} \text { ditolak } \\
\text { dan } \\
\mathrm{H}_{1} \text { diterima }\end{array}$ \\
\hline
\end{tabular}

Berdasarkan Tabel 10 maka dapat diketahui $t_{\text {tabel }}$ dengan taraf alpha 0,05 dengan jumlah responden 28 sebesar 2,06. Dengan demikian variabel variabel kesehatan kerja memiliki $t_{\text {hitung }}>t_{\text {tabel }}$ artinya $\mathrm{H}_{0}$ ditolak, $\mathrm{H}_{1}$ diterima. Jadi, kesehatan kerja mempunyai pengaruh yang signifikan terhadap produktivitas kerja karyawan.

f. Uji Kenormalan

Uji normalitas dilakukan untuk melihat apakah nilai residual terdistribusi normal atau tidak. Model regresi yang baik adalah memiliki nilai residual yang terdistribusi normal. Jadi uji normalitas bukan dilakukan pada masing-masing variabel tetapi pada nilai residualnya. Berikut adalah hasil pengolahan data uji kenormalan dengan menggunakan software SPSS 16.00

Tabel 11Output Residuals Statistics

\begin{tabular}{|l|r|r|}
\hline \multicolumn{3}{|c|}{ Residuals Statistics $^{\mathbf{a}}$} \\
\hline & \multicolumn{1}{|c|}{ Std. Deviation } & \multicolumn{1}{c|}{$\mathrm{N}$} \\
\hline Predicted Value & 3.370 & 28 \\
\hline Residual & 1.916 & 28 \\
\hline $\begin{array}{l}\text { Std. Predicted } \\
\text { Value }\end{array}$ & 1.000 & 28 \\
\hline Std. Residual & .962 & 28 \\
\hline \multicolumn{2}{|l|}{ Dependent Variable: $\mathrm{Y}$} \\
\hline
\end{tabular}

Normal P-P Plot of Regression Standardized Residual Dependent Variable: $Y$

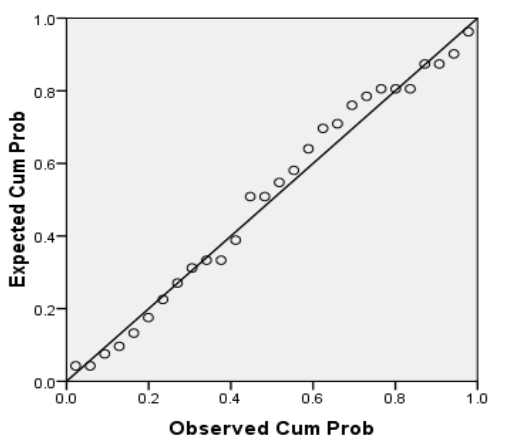

Gambar 2 Grafik Regresi

g. Koefisien Korelasi Berganda Analisis koefisien korelasi berganda digunakan untuk mengetahui keeratan hubungan antara keselamatan dan kesehatan kerja dengan peningkatan produktivititas kerja maka 
dilakukanlah analisis koefisien korelasi berganda.

Tabel 12Output Korelasi

\begin{tabular}{|c|c|c|c|c|}
\hline \multicolumn{5}{|c|}{ Correlations } \\
\hline & & $\begin{array}{c}\text { Keselamatan } \\
\text { Kerja } \\
\left(\mathrm{X}_{1}\right)\end{array}$ & $\begin{array}{c}\text { Kesehatan } \\
\text { Kerja } \\
\left(\mathrm{X}_{2}\right)\end{array}$ & $\begin{array}{c}\text { Produktivitas } \\
\text { Kerja } \\
\text { Karyawan } \\
(\mathrm{Y})\end{array}$ \\
\hline \multirow{3}{*}{$\left(X_{1}\right)$} & $\begin{array}{l}\text { Pearson } \\
\text { Correlation }\end{array}$ & 1 & $.830^{* *}$ & $.789^{* *}$ \\
\hline & $\begin{array}{l}\text { Sig. } \\
\text { (2-tailed) }\end{array}$ & & .000 & .000 \\
\hline & $\mathrm{N}$ & 28 & 28 & 28 \\
\hline \multirow{3}{*}{$\left(\mathrm{X}_{2}\right)$} & $\begin{array}{l}\text { Pearson } \\
\text { Correlation }\end{array}$ & $.830^{* *}$ & 1 & $.859^{* *}$ \\
\hline & $\begin{array}{l}\text { Sig. } \\
\text { (2-tailed) }\end{array}$ & .000 & & .000 \\
\hline & $\mathrm{N}$ & 28 & 28 & 28 \\
\hline \multirow{3}{*}{ (Y) } & $\begin{array}{l}\text { Pearson } \\
\text { Correlation }\end{array}$ & $.789^{* *}$ & $.859^{* *}$ & 1 \\
\hline & $\begin{array}{l}\text { Sig. } \\
\text { (2-tailed) }\end{array}$ & .000 & .000 & \\
\hline & $\mathrm{N}$ & 28 & 28 & 28 \\
\hline
\end{tabular}

Berdasarkan output diatas, adapun penarikan kesimpulan dengan merujuk pada dasar pengambilan keputusan uji korelasi adalah sebagai berikut:

1) Berdasarkan Nilai Signifikansi

Dari output di atas diketahui antara Keselamatan Kerja $\left(\mathrm{X}_{1}\right)$ dengan Kesehatan Kerja $\left(\mathrm{X}_{2}\right)$ nilai signifikansi $0,000<0,05$ yang berarti terdapat korelasi yang signifikan. Selanjutnya, antara Keselamatan Kerja $\left(\mathrm{X}_{1}\right)$ dengan Produktivitas Kerja Karyawan (Y) nilai signifikansi $0,000<0,05$ yang berarti terdapat korelasi yang signifikan. Terakhir, nilai signifikansi Kesehatan Kerja $\left(\mathrm{X}_{2}\right)$ dengan Produktivitas Kerja Karyawan (Y) nilai signifikansi $0,000<$ 0,05 yang berarti terdapat korelasi yang signifikan.

2) Berdasarkan Tanda Bintang SPSS

Dari output di atas diketahui bahwa Nilai Pearson Correlation yang dihubungkan antara masing-masing variabel mempunyai tanda bintang, ini berarti terdapat korelasi yang signifikan antara variabel yang dihubungkan.

\section{Kesimpulan}

Adapun kesimpulan yang dapat diambil dalam penelitian ini adalah sebagai berikut:

1. Jumlah jam kerja yang hilang akibat kecelakaan kerja di PT. Bormindo Nusantara bagian maintenance departement pada tahun 2014, 2015 dan 2016 yaitu masing-masingnya sebesar 97.344 jam kerja/ tahun.

2. Keselamatan dan kesehatan kerja mempunyai pengaruh terhadap produktivitas kerja karyawan. Hal itu sesuai dengan hasil dari perhitungan regresi dengan menggunakan Software SPSS versi 16.00 dari hasil analysis of variance (ANOVA) dengan uji $\mathrm{F}$ bahwa keselamatan dan kesehatan kerja berpengaruh terhadap produktivitas kerja karyawan dan memiliki hubungan positif.

3. Pengaruh antara keselamatan dan kesehatan kerja terhadap produktivitas kerja karyawan PT. Bormindo Nusantara bagian maintenance departement yaitu sebesar 73,6\% keselamatan dan kesehatan kerja dipengaruhi oleh produktivitas kerja karyawan dan 26,4\% dipengaruhi oleh faktor-faktor lain.

\section{Daftar Pustaka}

[1] Agustina, I., Faktor-Faktor Motivasi yang Mempengaruhi Kinerja Karyawan pada PT Gaya manunggal Kresitama, Jurnal Psikologi, Fakultas Psikologi, Universitas Guna Darma, Jakarta, 2009.

[2] Azwar, S., Reliabilitas dan Validitas, Pustaka Pelajar, Yogyakarta, 2012.

[3] Hakim, A., Analisa Kepuasan Pelaku Transportasi Terhadap Kinerja Mobil Penumpang Umum Jurusan BojonegoroBabat, Institut Teknologi Surabaya, Surabaya, 2010.

[4] Hendri, J., RisetPemasaran, MerancangKuesioner,

UniversitasGunadarma, Depok, 2009.

[5] Hutasoit, R. S., PengaruhPelaksanaan Program KeselamatandanKesehatanKerja (K3) 
TerhadapProduktivitasKerjaKaryawanpad

a PT. AdhiKarya (Persero)

TbkDivisiAspalt Mixing Plant (AMP)

Kawasan Medan, Skripsi,

JurusanManajemen, Universitas Sumatera

Utara, Medan, 2011.

[6] Janti,

S.,

AnalisisValiditasdanReliabilitasdenganSk alaLikertTerhadapPengembangan $\mathrm{Si} / \mathrm{Ti}$ dalamPenentuanPengambilanKeputusanP enerapanStrategic

PlanningpadaIndustriGarmen, Prosiding

Seminar

NasionalAplikasiSains\& Teknologi

(SNAST), AMIK BSI Jakarta, 2014.

[7] Koster, M. M., dan Boediono., Teori dan Aplikasi Statistika dan Probabilitas, PT. Remaja Rosdakarya, Bandung, 2001.

[8] Lestari,

T.,HubunganKeselamatandanKesehatanK

erja

denganProduktivitasKerjaKaryawan

(StudiKasus :BagianPengolahan PTPN VIII Gunung Mas, Bogor), Skripsi, JurusanManajemen, InstitutPertanian Bogor, Bogor, 2007.

[9] Pangarso, W. P., PengaruhKesehatandanKeselamatanKerja untukProduktivitasKerja (Study Kasus: CV. RigenSaranaMuktiKaranganyar, Surakarta), Skripsi, JurusanTeknikIndustri, Universitas Islam NegeriSunanKalijaga, Yogyakarta, 2014.

[10] Perdana, P., Nasution, F., danSudirwan, J.,

AnalisisKecelakaanKerjaUntukPeningkat anProduktivitasdenganPenerapanSistemIn formasipada PT ArtistikaKreasiMandiri, Diperolehdarihttp://thesis.binus.ac.id/doc /Lain-lain/2012-200244TISI\%20WorkingPaper001.pdf pada 2 Maret 2017.
[11] Riantiwi, A., HubunganPelaksanaan Program K3

DenganProduktivitasKerjaKaryawanPada DivisiOperasional PT Surveyor Indonesia, Skripsi, JurusanIlmuAdministrasi, Univeritas Indonesia, Depok, 2012.

[12] Sitania, F. D., danSoleman, A., PedomanKesehatandanKeselamatanKerja padaIndustriKerajinanKerangMutiara, JurnalTeknikIndustriUniversitaspattimura , Vol. 05 IX, No. 2, Agustus, 2011, pp. 131.

[13] Suma'mur., Keselamatan Kerja dan Pencegahan Kecelakaan, PT. Toko Gunung Agung, Jakarta, 1981.

[14] Sungkawa, Iwa., Penerapan Analisis Regresi dan Korelasi dalam Menentukan Arah Hubungan Antara Dua Faktor Kualitatif Pada Tabel Kontingensi, Jurnal Mat Stat Vol. 13 No. 1 33-41, Departemen Statistika dan Matematika, Universitas Binus, Jakarta Barat, 2013.

[15] Wulansari, D. D.,Pemakaian Alat Pelindung Diri Sebagai Upaya dalam Pencegahan Kecelakaan Kerja di Bagian Granule Di PT. Bina Guna Kimia Ungaran, Skripsi, Jurusan Hiperkes dan Keselamatan Kerja, Universitas Sebelas Maret, Surakarta, 2009. 